\title{
A ADVOCACIA PÚBLICA COMO INSTITUIÇÃO ESSENCIAL AO ESTADO DE DIREITO DEMOCRÁTICO E SOCIAL
}

\author{
Marcus Gouveia dos Santos ${ }^{1}$
}

RESUMO: O presente artigo tem como objeto a função constitucional da Advocacia Pública, pretendendo demonstrar a sua natureza de princípio garantia para a consolidação dos princípios estruturantes do Estado de Direito Democrático e Social. Para alcançar este propósito, formularam-se os seguintes objetivos: a) analisar a trajetória histórica de reconhecimento do Estado de Direito Democrático e Social na Constituição; b) analisar o percurso histórico e as respectivas funções da Advocacia Pública no Estado de Direito; c) demonstrar as consequências da adoção do Estado de Direito Democrático e Social como princípio estruturante da Constituição Brasileira, considerando, entre outros aspectos, a influência sobre a concretização da dignidade da pessoa humana. Do ponto de vista metodológico, desenvolveu-se pesquisa descritiva, cujas fontes principais foram: a Constituição Brasileira, a legislação nacional e a doutrina produzida por juristas de diferentes países, que trazem a lume alguns consensos e divergências quanto à função constitucional da Advocacia Pública para a consolidação dos princípios estruturantes. Ao final, apresentam-se considerações no intuito de contribuir para a garantia dos princípios constitucionais estruturantes, por meio de uma concepção constitucionalmente adequada do papel da Advocacia Pública.

Palavras-Chave: Advocacia Pública; Estado de Direito; Estado Social; Direitos Fundamentais.

ABstract: The current article has as its main object the role of Public Advocacy in the Brazilian Constitution, intending to demonstrate the guarantee nature of this principle for the consolidation of the structuring principles of Democratic and Social State of Law. In order to achieve this purpose, the following objectives will be pursued: a) analyzing Democratic and Social State of Law's historical development until its constitutional recognition; b) analyzing Public Advocacy's

\footnotetext{
${ }^{1}$ Doutorando em Ciências Jurídico- Políticas, especialidade Direito Constitucional, pela Faculdade de Direito da Universidade de Lisboa; Mestrado em Ciências Jurídico- Políticas, especialidade Direito Constitucional, pela Faculdade de Direito da Universidade de Lisboa. E-mail: marcusgouveia1977@gmail.com. ORCID: 0000-0002-3400-0047 (disponível em https://orcid.org/0000-0002-3400-0047).
} 
historical development and functions on Rule of Law; c) demonstrating the consequences of adopting the Democratic and Social State of Law as a structuring principle of the Brazilian Constitution, considering, among other aspects, its influence on realization of human's dignity. From methodological point of view, a descriptive research has been developed, having these main sources: Brazilian Constitution, national Law and doctrine produced by great thinkers from different countries, which intends to bring to light some consensus and divergences regarding the constitutional function of Public Advocacy for concretization of the structuring principles. By the end, the author's considerations will be presented, in order to contribute to the guarantee of structuring constitutional principles, through an adequate constitutional role of Public Advocacy.

KeYwORDS: Public Advocacy; Rule of Law; Social State; Fundamental Rights.

\section{INTRODUÇÃO}

A consolidação da Advocacia Pública como instituição essencial à Justiça confunde-se com o próprio percurso histórico do Estado de Direito Democrático e Social.

Conforme se demonstrará no presente trabalho, até a sedimentação de suas funções na Constituição Federal de 1988, a Advocacia Pública desempenhou diversas tarefas, desde a defesa do patrimônio do monarca no Estado Patrimonial e do Fisco no Estado de Polícia até a confusão de atribuições com o Ministério Público.

Nesse processo histórico constitucional de consolidação do Estado de Direito Democrático e Social, não se mostra mais acertado o entendimento de que à Advocacia Pública caberia somente a defesa dos interesses patrimoniais do Estado, muito menos de que seria um órgão garantidor da vontade do governante.

Como instituição responsável pela garantia dos interesses do Estado, assim entendido como Estado de Direito Democrático e Social, é papel constitucional da Advocacia Pública zelar pelos princípios do Estado de Direito, democrático e da socialidade, em favor da concretização dos valores materiais previstos na Constituição. Isto porque o Poder Constituinte não almejou uma justiça meramente formal, mas também substancial e social.

Para tanto, conforme será observado, é essencial que Advocacia Pública goze de certas prerrogativas que lhe assegurem independência e autonomia para o 
exercício de sua função constitucional de concretização de um ideal de justiça em um Estado de Direito Democrático e Social.

Portanto, ao longo do presente trabalho, abordar-se-á a evolução do conceito atual do Estado de Direito e da própria Advocacia Pública, com o intuito de defendê-la como instituição garantia do Estado de Direito Democrático e Social e comprometida com a concretização dos valores materiais constitucionais.

\section{O ESTADO DE DIREITO DEMOCRÁTICO E SOCIAL COMO PRINCíPIO ESTRUTURANTE DA CONSTITUIÇÃo BRASILEIRA}

Após um regime ditatorial de mais de 20 anos, a Constituição Federal de 1988 resultou de uma intensa discussão política a respeito das diversas ideologias que permeavam a sociedade brasileira e que deveriam ser adotadas pela Carta Constitucional. $\mathrm{O}$ embate entre as antigas e as novas forças políticas e sociais conferiu um caráter pluralista à Constituição, moldando a maneira do Poder Público se relacionar com o indivíduo. Dentre as correntes que inspiraram a nova Constituição, além de uma preocupação com a liberdade individual e com a instauração de uma ordem democrática, havia um forte anseio de que esse documento jurídico fosse um instrumento transformador da realidade social e de redução das desigualdades (SILVA, 1998, p. 90-92; BARROSO, 2012, p. 09-46).

Como a Constituição Cidadã era o reflexo natural das ideologias dominantes na sociedade brasileira, os diversos valores foram encampados no sistema jurídico constitucional por meio de princípios. ${ }^{2}$ Alguns desses princípios, pela relevância que possuem, são denominados de princípios constitucionais estruturantes. Podese dizer, assim, que os princípios constitucionais estruturantes são os responsáveis pela previsão dos principais valores que inspiram a Constituição Brasileira, através dos quais se permite determinar a sua própria essência e natureza, vinculando todos os poderes constituídos e direcionando a interpretação e a aplicação de todas as normas constitucionais (BONAVIDES, 2003, p. 66-67).

Segundo Canotilho (2003, p. 1173) "existem, em primeiro lugar, certos princípios designados por princípios estruturantes, constitutivos e indicativos das ideias directivas básicas de toda a ordem constitucional." Sem a pretensão de apontar taxativamente os princípios estruturantes, informa que os princípios estruturantes da Constituição Portuguesa são o princípio do Estado de Direito, o princípio democrático e o princípio republicano.

\footnotetext{
2 Conforme Jorge Miranda (2007, p. 198), o Direito Constitucional está “(...) todo ele envolvido e penetrado pelos valores jurídicos fundamentais dominantes na comunidade". Peter Häberle (2002) diz que a própria concepção de "Constituição Aberta", revela justamente a importância dos valores sociais para a interpretação e formulação da norma constitucional.
} 
Conforme menciona Canotilho (2003, p. 1173-1175), estes princípios estruturantes são densificados por princípios constitucionais gerais ou especiais e por regras constitucionais. O princípio do Estado de Direito seria concretizado por meio dos seguintes princípios gerais: princípio da constitucionalidade, princípio da legalidade da administração, princípio da vinculação do administrador aos direitos fundamentais, princípio da independência dos Tribunais. Esses princípios gerais do Estado de Direito poderiam ser densificados ainda em princípios especiais. O princípio estruturante Republicano seria densificado através do princípio da não- vitaliciedade dos cargos políticos, princípio da igualdade civil e política, dentre outros. Já o princípio estruturante democrático seria densificado pelos princípios da soberania popular, do sufrágio universal, da participação democrática dos cidadãos, da separação e interdependência dos órgãos de soberania, dentre outros. $\mathrm{O}$ princípio democrático na sua dimensão da democracia econômica, social e política seria densificado pelo princípio da socialidade, que seria responsável por concretizar os direitos econômicos, sociais e culturais.

Analisando os princípios conformadores e determinantes da Constituição Alemã, Bökenförde (2000, p. 118-131) defende que os princípios estruturantes seriam o Estado de Direito (artigo 20.3 e artigo 28.1), a forma republicana (artigo 20.1 e artigo 28.1), o Estado Social (artigo 20.1 e artigo 28.1) e a democracia (artigo 28.1). Menciona o autor que esses princípios possuem características convergentes e elementos que se contrapõem, mas devem ser interpretados conjuntamente sob a menção de Estado de Direito Social e Democrático, para se atingir o mesmo fim.

Especificamente quanto aos princípios estruturantes da Constituição Federal Brasileira, o artigo $1^{o}$ prevê que a República Federativa do Brasil constitui- se em um Estado Democrático de Direito. Tendo em vista a omissão no tocante ao princípio estruturante do Estado Social, em um primeiro momento, poder-se-ia concluir equivocadamente que o mesmo não seria um valor delimitador da natureza e da essência da Constituição de 1988.

Entretanto, embora a natureza social do Estado não esteja prevista no caput do artigo $1^{\circ}$, tendo em vista os inúmeros direitos sociais previstos no texto constitucional, o princípio da socialidade é indissociável do Estado Democrático de Direito (SARLET, 2007, p. 69-74; BONAVIDES, 2011, p. 370-375; BONAVIDES, 2003, p. 87-90; FILHO, 2015, p. 346-347; CUNHA JÚNIOR, 2015, p. 119-120). Esse é o entendimento de Ferreira Filho (2015, p. 347), no sentido de que "os direitos sociais são de grande relevância para o Estado social de Direito que consagra a atual Constituição ao falar imprecisamente em Estado democrático de Direito."

Dessa forma, na expressão "Estado Democrático de Direito", prevista no caput do artigo $1^{\circ}$, estão sedimentados os três princípios resultantes da evolução do Estado, quais sejam, o princípio do Estado de Direito em sentido estrito, o princípio democrático e o princípio da socialidade, que são indissociáveis. São esses três princípios que compõem o Estado de Direito das sociedades 
democráticas atuais e constituem os princípios estruturantes da Constituição Brasileira.

Não há uma vinculação existencial necessária entre os princípios estruturantes, uma vez que, por exemplo, ao longo da história já existiu Estado de Direito sem democracia (Monarquia Constitucional Brasileira da Carta de 1824 e Monarquia Constitucional Alemã do século XIX). Todavia, embora os princípios estruturantes tenham conteúdo distintos, são indissociáveis no atual Estado Constitucional e convergem para um mesmo fim.

Como adverte Habermas (2015, p. 123-134) “estes motivos empíricos para um tratamento acadêmico destes dois objetos, caracterizados pela divisão do trabalho, ainda não significam, de modo algum que, sob o ponto de vista normativo, possa existir um Estado de direito sem democracia". Isto porque o processo histórico de sedimentação do Estado de Direito Democrático e Social e a sua previsão na Constituição importa que haja um vetor comum no qual se confluem o Estado de Direito, a democracia e o Estado Social.

$\mathrm{O}$ princípio democrático tem um caráter preponderantemente orgânico e formal, diz respeito a quem é o titular do poder estatal, ou seja, se refere à formação, à legitimação e ao controle dos órgãos que exercem o poder organizado do Estado. O Estado de Direito, por sua vez, tem caráter material e procedimental, constitui a maneira como deve proceder a atividade estatal, impondo limites e vinculando o Estado como forma de garantir a liberdade individual e social, notadamente através do reconhecimento de direitos fundamentais, da legalidade administrativa e da proteção jurídica por meio de Tribunais Judiciais independentes. Por outro lado, a previsão do Estado Social na Constituição não se trata de um princípio de legitimação ou de delimitação do poder estatal, como os princípios democrático e do Estado de Direito, respectivamente, mas sim de estabelecimento de um determinado fim ao Estado (BÖCKENFÖRDE, 2000, p. 118-131; HABERMAS, 2015, p. 123-134).

Dentre os objetivos comuns aos princípios constitucionais estruturantes estão a garantia e a promoção da dignidade da pessoa humana, núcleo duro essencial e inviolável dos direitos fundamentais. Segundo Canotilho (2003, p. 1185-1186), os princípios constitucionais estruturantes se reconduzem ao homem, como pessoa (Estado de Direito), como cidadão (princípio democrático) e como trabalhador (princípio da socialidade).

A dignidade da pessoa humana constitui-se em um princípio metajurídico, fim último de toda a ordem constitucional e fundamento de um autêntico Estado de Direito Democrático e Social. Enquanto elemento axiológico central da atual concepção de Estado de Direito, faz com que este deixe de ser percebido sob a sua concepção meramente formal, no sentido de que somente sejam direitos subjetivos aqueles expressamente reconhecidos como tal pelo Estado. Como consequência, o Estado de Direito material impõe a existência de direitos inatos ao ser humano, capazes de limitar todos os poderes constituídos. 
A dignidade da pessoa humana representa uma garantia não somente do núcleo essencial dos direitos de liberdade, de forma a assegurar uma esfera inviolável da autonomia privada e pública do cidadão, mas também exerce uma função decisiva de impulsionar a vontade do Estado no sentido de promover a igualdade material e a justiça social (NOVAIS, 2004. p. 15- 45; MIRANDA, 2011, p. 01-18). Dessa forma, impõe uma configuração ao poder de decisão do Estado, no sentido de que não só direciona o exercício do poder político a uma ordem e lhe dá forma, como também o limita e o vincula em conteúdo e alcance (BÖCKENFÖRDE, 2000, p. 118-131; HABERMAS, 2015, p. 123-134). Portanto, os princípios democrático, da socialidade e do Estado de Direito somente ganham sentido e são legitimamente justificados quando apontem para a concretização dos valores materiais constitucionais, notadamente a dignidade da pessoa humana.

Decorrente do aspecto axiológico da dignidade da pessoa humana, os valores materiais agregaram uma dimensão objetiva aos direitos fundamentais, além da tradicional perspectiva subjetiva, que vincula todos os órgãos estatais. A normatividade conferida aos valores materiais ganhou relevância após as atrocidades cometidas contra seres humanos durante a $2^{\text {a }}$ Guerra Mundial, fazendo com que fossem irradiados para toda ordem jurídica, impondo a Constituição como norma jurídica superior e vinculante de todos os Poderes Constituídos, mitigando a separação entre direito público e direito privado (SARMENTO, 2006. p. 105- 140; BARROSO, 2012, p. 09-46; NOVAIS, 2018, p. 106110).

A eficácia irradiante da dimensão objetiva importa em considerar que os valores que consubstanciam os direitos fundamentais sejam refletidos para toda a ordem jurídica. Mesmo os tradicionais direitos de liberdade deixam de ser meros limites ao poder estatal e se transformam em diretrizes para a ação positiva estatal, vinculando a atuação do Legislativo, do Executivo e do Judiciário (ANDRADE, 2012, p. 229-262; SARLET, 2007, p. 398-407; SARMENTO, 2010, p. 105140; NOVAIS, 2018, p. 106-110; ALEXY, 2015, p. 105-116). Com fundamento na eficácia irradiante, os órgãos estatais devem pautar suas ações à luz dos principais valores consagrados no texto constitucional, como a dignidade da pessoa humana, o pluralismo, a justiça social e a igualdade material (SARMENTO, 2006, p. 124-129).

A própria legislação infraconstitucional deve ser interpretada em conformidade com essa nova carga axiológica derivada dos direitos fundamentais, o que a doutrina denomina de filtragem constitucional. Em virtude da elasticidade das cláusulas gerais e dos conceitos jurídicos indeterminados, estes são mais sujeitos à eficácia irradiante, permitindo que sejam preenchidos com novos conteúdos, inspirados nos valores materiais.

Em assim sendo, os balizamentos impostos pelos princípios estruturantes e os respectivos valores materiais orientam diretamente a atuação do advogado 
público. Como instituição essencial à justiça, o compromisso constitucional da Advocacia Pública não é com uma mera justiça formal, mas com uma justiça de cunho substancial e social.

\section{O PROCESSO HISTÓRICO DE SEDIMENTAÇÃO CONSTITUCIONAL Da Advocacia Pública}

A Advocacia Pública teve um longo percurso até restar consolidada na Constituição Federal de 1988, como instituição essencial à justiça e à garantia do Estado de Direito Democrático e Social. Esse processo histórico de sedimentação constitucional da Advocacia Pública confunde-se com a própria evolução do conceito de Estado de Direito.

Uma primeira remissão à Advocacia Pública brasileira consiste na figura do Procurador dos Feitos da Coroa, ainda no Brasil Colônia, previsto nas Ordenações Afonsinas do ano de 1446. A atribuição do Procurador dos Feitos da Coroa era basicamente a defesa do Estado Patrimonial, cuja propriedade se confundia com o patrimônio pessoal do monarca (Livro I, do seu Título IX). Além da defesa do direito e dos bens reais, lhe incumbia a defesa de órfãos, viúvas e pobres (Livro I, do seu Título VIII).

As Ordenações Manuelinas de 1521 mantiveram as funções do Procurador dos Feitos da Coroa, salvo quanto à defesa de órfãos, viúvas e pobres, que passaram a ser tutelados pelo Promotor da Justiça da Casa de Suplicação. Assim como tratado pelas Ordenações Afonsinas, a atuação do Procurador dos Feitos da Coroa estava atrelada à consolidação do Estado Absolutista, nessa fase denominado de Estado Patrimonial.

Em 1603, com o advento das Ordenações Filipinas, além do Procurador dos Feitos da Coroa e do Promotor da Justiça da Casa de Suplicação, foi criado o cargo de Procurador dos Feitos da Fazenda, com atribuições inerentes aos feitos fazendários (MADUREIRA, 2015, p. 199-214). Esse período marca a transição do Estado Absolutista Patrimonial para o Estado de Polícia, o primeiro caracterizado pelo Estado ser considerado parte integrante do patrimônio real e o segundo pelo monarca deixar de ser proprietário do Estado e passar a ser seu servidor (NOVAIS, 2004, p. 15-19; NOVAIS, 2017. p. 27-40; DI PIETRO, 2006, p. 23-66).

A característica marcante do Estado de Polícia era o despotismo esclarecido e a concentração do poder na pessoa do rei, justificado pela razão, dotando o monarca do poder de intervir nas esferas política, social, econômica e particular, sob o pretexto de objetivar o interesse público. Como o interesse público se confundia com a vontade do monarca e esta estava acima do próprio direito, os interesses individuais deveriam sempre ceder diante do interesse estatal.

Uma vez que os atos do soberano não estavam submetidos ao direito e, muito menos, aos Tribunais, surgiu a figura do Fisco. Como as compensações materiais pelos prejuízos causados pelo Estado de Polícia não poderiam ser reivindicadas 
do monarca, os súditos passaram a poder cobrá-las do Fisco. No entanto, mesmo com a instituição do Fisco para a reparação financeira pelos prejuízos causados pela atuação do Estado, a possibilidade de intervenção ilimitada e arbitrária na vida do súdito e a ausência de regras preestabelecidas para regular a atuação estatal eram motivos de grande insegurança e injustiça (NOVAIS, 2004, p. 15-19; NOVAIS, 2017, p. 27-40; DI PIETRO, 2006, p. 23-66).

Ainda na fase do Estado de Polícia, no ano de 1609, o Rei Felipe II instituiu a Relação do Estado do Brasil para a boa administração da Justiça, com a instituição do cargo de Procurador dos Feitos da Coroa, Fazenda e Fisco e Promotor de Justiça. Os três cargos previstos nas Ordenações Filipinas tiveram suas funções reunidas em somente um, precisamente pela escassez de funcionários para a instalação da Relação do Estado do Brasil. Por conta disso, segundo alguns autores, esse é o motivo pelo qual, até a Constituição de 1988, houve uma cumulação indevida da função de defesa dos interesses da sociedade e dos interesses do Estado pelo Ministério Público.

Com a vinda da família real portuguesa para o Brasil, em 1808, foi conferida autonomia à organização judiciária brasileira em relação à metrópole, com a instituição da Casa de Suplicação do Brasil, que funcionava como uma instância superior aos Tribunais da Relação existentes. O antigo Procurador dos Feitos da Coroa, Fazenda e Fisco e Promotor de Justiça passou a ser denominado de Procurador dos Feitos da Coroa e Fazenda e, posteriormente, por conta do Decreto editado em 1823, foi intitulado de Procurador da Coroa, Soberania e Fazenda Nacional (MADUREIRA, 2015, p. 199-214).

A mudança da corte portuguesa também culminou com a declaração de independência e a instauração da Assembleia Constituinte. Devido ao caráter liberal do projeto Constitucional, que limitava os poderes do monarca, D. Pedro I dissolveu a Assembleia Constituinte e outorgou a Constituição Federal de 1824. Embora ainda se constate a concentração de poderes na figura do imperador (Poder Moderador), resquício do absolutismo e do Estado de Polícia, verifica-se uma preocupação com os direitos individuais e políticos, decorrente da encampação dos novos valores advindos da Revolução Francesa.

Dessa forma, com a Constituição de 1824, inaugurou-se o Estado de Direito no Brasil, assim considerado aquele em que o poder político é organizado e limitado pelo direito. Dentre outros aspectos, a submissão do Estado ao direito importava que o Estado fosse entendido como pessoa jurídica, detentor de direitos e obrigações; que a relação entre Estado e particular fosse tutelada pelo direito e submetida ao Tribunal; que fosse adotada a divisão de poderes; e que fosse adotada uma hierarquia entre as normas jurídicas, de forma que os atos estatais pudessem ser controlados por uma norma hierarquicamente superior (NOVAIS, 2004, p. 15-19; NOVAIS, 2017, p. 27-40; MIRANDA, 2011, p. 01-18).

Embora mantidas as funções, a nomenclatura do Procurador da Coroa, Soberania e Fazenda Nacional foi alterada para Procurador da Coroa e Soberania. 
Além disso, no período que antecedeu à Constituição de 1824, foi instalado o Conselho de Procuradores Gerais das Províncias do Brasil, cuja função era prestar assessoria jurídica e legislativa ao Imperador Dom Pedro I. Na vigência da Constituição de 1824, foram ainda criados os cargos de Procurador da Fazenda e de Procurador Fiscal (Lei no 242/1841 e Decreto nº 736/1850).

Com a proclamação da República em 1889 e sob inspiração da Constituição norte-americana, adveio a Carta de 1891, que adotou um modelo constitucional fundado no Estado de Direito Liberal, marcado pelo abstencionismo estatal e pela preocupação com a liberdade individual. O antigo cargo de Procurador da Coroa e Soberania passou a ser denominado de Procurador da República (artigo 58, §2º da Constituição). Através do Decreto no 967/1903, também foi previsto o cargo de Consultor Geral da República, com a atribuição de consultoria jurídica no âmbito federal, bem como, posteriormente, por meio do Decreto 7.751/1909, foi instituído o cargo de Procurador da Fazenda, com atribuição para cobrança judicial de dívidas em favor da União.

Essa organização foi mantida pelas Constituições de 1934 e 1937 e, salvo no tocante a alguns reparos, pela Constituição de 1946. Assim sendo, antes da promulgação da atual Constituição Federal, a representação jurídica da União Federal era exercida pelo Ministério Público, que cumulava as tarefas de defesa dos interesses da sociedade e dos interesses do Estado. Tal fato comumente acarretava a defesa de interesses contraditórios perante o Poder Judiciário (MADUREIRA, 2015, p. 199-214).

Nesse interregno, digno de nota foi a transição do Estado de Direito Liberal para o Estado de Direito Social, que repercutiu na relação da Administração Pública com o cidadão e na própria atividade da Advocacia Pública. Isto porque a adoção do Estado Social pela Constituição de 1934 importou em um abandono do abstencionismo estatal e, consequentemente, uma intervenção do Poder Público na economia e na sociedade. Embora as normas constitucionais de direitos sociais ainda tivessem natureza programática antes da promulgação da Constituição Cidadã de 1988, a necessária intervenção econômica e social em favor da promoção da justiça social exacerbava a contradição da concentração das funções de defesa do Estado e de tutela dos interesses da sociedade na figura do Ministério Público (artigo 95 da Constituição de 1934).

A Constituição Federal de 1988 corrigiu essa distorção, conferindo aos advogados públicos as tarefas de consultoria jurídica e assessoramento jurídico do Poder Executivo, bem como de representação judicial e extrajudicial do ente público (artigo 131). Ao passo que ao Ministério Público foi reservada a função de tutela da ordem jurídica, do regime democrático e dos interesses sociais e individuais indisponíveis (artigo 127).

Especificamente quanto ao papel constitucional da Advocacia Pública, enquanto o artigo 131 trata da representação judicial e extrajudicial da União Federal pela Advocacia- Geral da União, o artigo 132 prevê a representação 
judicial e extrajudicial dos Estados e do Distrito Federal pelos respectivos procuradores. Nesse aspecto, a Advocacia Pública está consagrada no Título IV, que trata "Da Organização dos Poderes", no Capítulo IV, intitulado de "Funções Essenciais à Justiça". Percebe-se, assim, que a Advocacia Pública não constou do Capítulo II, que regulamenta o Poder Executivo, mas sim em Seção própria (Seção II) do Capítulo IV, como princípio garantia do Estado de Direito Democrático e Social, cuja competência está fixada na própria Constituição Federal.

Vale ressaltar que, embora a Constituição Federal não tenha consagrado a Advocacia Pública Municipal, para que haja um efetivo controle interno da juridicidade dos atos da Administração Pública Municipal, que inclusive possa resistir à vontade pessoal dos gestores públicos, necessário que os procuradores municipais sejam investidos em cargos públicos, mediante aprovação em concurso Público. Por simetria, devem ser aplicados os preceitos constitucionais aplicáveis à Advocacia- Geral da União e às Procuradorias Estaduais e do Distrito Federal (MADUREIRA, 2015, p. 187-196). Em um Estado de Direito Democrático e Social, não faria sentido que a Advocacia Pública Municipal fosse exercida por escritórios particulares contratados ou por advogados ocupantes de cargos em comissão, na medida em que, por serem contratações de caráter precário, não deteriam autonomia suficiente para o exercício do controle da juridicidade dos atos praticados pelos administradores municipais.

Em todos os níveis federativos, a autonomia técnica é inerente ao desempenho da função. A autonomia técnica do advogado público é garantida pelo artigo $7^{\circ}$,

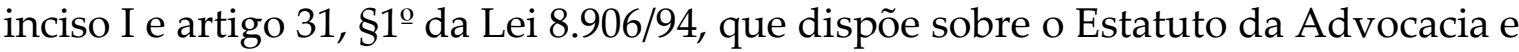
a Ordem dos Advogados do Brasil. Como os advogados públicos exercem a atividade de advocacia, nos termos do artigo $3^{\circ}, \S 1^{0}$ da citada Lei, gozam das mesmas prerrogativas outorgadas aos advogados em geral, principalmente a independência e a liberdade no exercício de sua função (artigo $7^{\circ}$ e artigo 31, §1ํㅜ).

Aliás, não faria qualquer sentido atribuir à Advocacia Pública o controle interno da atividade administrativa, mas privar-lhe da independência e da liberdade necessárias ao desempenho de sua tarefa constitucional. Por isso, afirma Moreira Neto (2009, p. 46) que "a própria Constituição lhes assegura a independência técnico-funcional". Da mesma forma, a Súmula no 7 da Comissão Nacional da Advocacia Pública do Conselho Federal da $\mathrm{OAB}^{3}$ estabelece que a independência técnica é prerrogativa inata ao exercício da advocacia pública. Os limites dessa independência técnica são traçados pela própria Constituição, pelo

\footnotetext{
3 Súmula no 2 da Comissão Nacional da Advocacia Pública do Conselho Federal da OAB: "A independência técnica é prerrogativa inata à advocacia, seja ela pública ou privada. A tentativa de subordinação ou ingerência do Estado na liberdade funcional e independência no livre exercício da função do advogado público constitui violação aos preceitos Constitucionais e garantias insertas no Estatuto da OAB." Em idêntico sentido é o Parecer no GQ-24, da AdvocaciaGeral da União, aprovado pelo Presidente da República e, por isso, de cumprimento compulsório pela Administração Federal".
} 
Estatuto da Advocacia e pela Lei Orgânica da Procuradoria que disciplina a atuação do advogado público.

A atividade de consultoria jurídica tem como objetivo orientar os agentes públicos sobre a interpretação e aplicação do direito quanto aos fatos administrativos que se apresentem. Em um Estado de Direito Democrático e Social, a Advocacia Pública não deve meramente legitimar decisões administrativas determinadas pelos gestores da coisa pública (MADEIRA, 2010; MADUREIRA, 2015. p. 303-309). No âmbito consultivo deve o advogado público zelar pelo controle interno da juridicidade da atuação estatal e sugerir a revisão de atos administrativos, através do exercício da autotutela administrativa, que sejam contrários aos valores do Estado de Direito Democrático e Social.

No plano processual deve resguardar a juridicidade do ato administrativo em face de pretensões individuais infundadas ou, inclusive, rever atuações judiciais para adequação ao interesse público de concretizar os princípios que consubstanciam o Estado de Direito Democrático e Social. Em regime de cooperação com os demais sujeitos do processo, ao advogado público cabe zelar por uma decisão de mérito justa e efetiva, como prevê o artigo $6^{0}$ do Código de Processo Civil. Isso importa na possibilidade de realizar conciliação, de desistir de ações e de abster-se de apresentar defesas e recursos flagrantemente infundados (MADUREIRA, 2015, p. 309-340).

\section{O Papel da Advocacia Pública no Estado de direito DEMOCRÁTICO E SOCIAL}

Como já mencionado acima, o Estado de Direito Democrático e Social é o resultado histórico da consolidação nas Constituições contemporâneas dos princípios do Estado de Direito, do democrático e da socialidade. O Estado de Direito importa na limitação e vinculação do Poder Público, por meio do reconhecimento de direitos fundamentais, da legalidade administrativa e da tutela jurídica por meio de um Poder Judiciário independente. Por sua vez, a democracia impõe a formação e o exercício do Poder de forma legítima, inclusive através do controle e da fiscalização dos órgãos de representação democrática. Por fim, a socialidade direciona a atuação do Poder Público em favor da igualdade material e social.

Estes princípios estruturantes são as "traves mestras jurídico- constitucionais do estatuto jurídico do político" (CANOTILHO, 2003, p. 1173), concretizando-se por meio de princípios gerais ou específicos. Tanto os princípios estruturantes, como os princípios gerais ou específicos, devem ter como propósito principal a garantia e a promoção dos valores materiais, consubstanciados primordialmente na dignidade da pessoa humana.

Dentre os princípios que devem pautar a atuação da Administração Pública e que densificam os princípios estruturantes estão os princípios da legalidade, da 
impessoalidade, da publicidade, da moralidade e da eficiência, previstos no artigo 37 da Constituição Federal, bem como o princípio da supremacia do interesse público. Segundo Di Pietro (2006, p. 81-85), os dois principais princípios do Direito Administrativo são o princípio da legalidade e o princípio da supremacia do interesse público, porque, a partir deles, constroem- se todos os demais.

Em um Estado de Direito Democrático e Social, a vinculação do Poder Público ao princípio da legalidade deve estar atrelada ao ideal de justiça. Isto porque a Administração não deve estar submetida somente à lei, em sentido puramente formal, mas ao Direito como um todo, principalmente aos valores consagrados na Constituição (DI PIETRO, 2006, p. 49-58). Como instituição essencial à Justiça, a Advocacia Pública deve estar comprometida com uma justiça substancial e social, não meramente formal, uma vez que sem igualdade material não há efetivo exercício de direitos de liberdade ou políticos, restando frustrado o próprio fim do Estado de Direito Democrático e Social.

Por sua vez, como conceito jurídico indeterminado e fim último da Administração, o próprio interesse público deve ter seu conteúdo norteado pelos princípios estruturantes e pelos valores materiais constitucionais. Com isso, é equivocada a distinção realizada por parte da doutrina de que seria função da Advocacia Pública a defesa do interesse público secundário e ao Ministério Público caberia a defesa do interesse público primário.

Segundo essa doutrina, o interesse público primário é a razão de ser do Estado, consistindo na finalidade do Estado de promover a justiça, a segurança e o bem-estar social, cuja atribuição constitucional para a tutela é do Ministério Público (BARROSO, 2005, p. xiii- xiv; MAZZILLI, 2008, p. 47-48). Por sua vez, o interesse público secundário decorre de uma relação jurídica em que a União, o Estado, o Município ou suas autarquias sejam parte, identificado com o interesse do erário de maximizar as receitas e minimizar as despesas, cuja defesa seria atribuição da Advocacia Pública.

A Constituição de 1988, ao consagrar um Estado de Direito Democrático e Social, não se compatibiliza com a concepção de que seria tarefa da Advocacia Pública a defesa de um Estado de Polícia, em que ao advogado público incumbiria a tutela dos interesses do Fisco, muito menos de um Estado Patrimonial, cuja propriedade e o interesse se confundem com os dos governantes.

Como adverte Justen Filho (1999, p. 118), não é finalidade do Estado a obtenção de lucro, notadamente quando esta seja revestida de duvidosa valia ética. Embora Bandeira de Mello (2012, p. 65-66) também classifique o interesse público em primário (interesse dos indivíduos enquanto partícipes da sociedade) e em secundário (interesse particular ou individual do Estado), aduz que a perseguição do interesse secundário pelo Estado somente será legítima quando coincidir com o interesse primário. 
Em um Estado de Direito Democrático e Social, a atuação do Poder Público deve ser sempre direcionada e legitimada pelos valores materiais constitucionais. Assim, como instituição garantia do Estado de Direito Democrático e Social, a Advocacia Pública deve moldar sua atuação nos princípios do Estado de Direito, democrático e da socialidade, em favor da concretização dos mencionados valores.

Ao contrário do que se possa imaginar, os valores materiais que legitimam a atuação do Poder Público nem sempre apontam para a garantia de um direito fundamental. Muitas vezes, o interesse público deve prevalecer sobre um direito fundamental, notadamente quando coincidir com a concretização de valores materiais previstos na Constituição.

A distinção lecionada por Dworkin (1999, p. 455-456; p. 474; 2011, p. 208-209), entre interesses fundados em direitos (rights and principles) e interesses baseados em fins estatais ou comunitários (polices), desconsidera que grande parte dos direitos fundamentais no Estado de Direito Social depende de uma política estatal (NOVAIS, 2010, p. 319-331; NOVAIS, 2012. p. 37-63; NOVAIS, 2007, p. 79- 113; COMELLA, 2011, p. 153-167). Na concepção de trunfos contra a maioria, Dworkin sustenta que em um Estado de Direito não se pode restringir direitos fundamentais sob o fundamento de se estar garantindo o bem comum ou um fim público. Como os direitos fundamentais seriam direitos morais contra a maioria, as decisões políticas da maioria que afetem esses direitos não seriam legítimas, mesmo quando objetivassem assegurar um fim público.

Entretanto, não se pode entender o Estado como um inimigo dos direitos fundamentais, muitas vezes o próprio direito fundamental depende de uma atuação do Poder Público para se tornar exigível. Dessa forma, a concepção de trunfos contra a maioria de Dworkin deve ser adaptada aos valores previstos na Constituição de 1988. A consagração de um Estado de Direito de caráter Social importou na respectiva interferência estatal na sociedade e na possibilidade de restrição de direitos individuais em favor da promoção de uma justiça social.

A concepção de Dworkin (1999, p. 455-456; p. 474; 2011, p. 208-209) desconsidera que, para a efetivação de direitos prestacionais, pode ser necessária a restrição de outros direitos fundamentais, como forma de realização de uma política pública estatal em favor da justiça social e da igualdade material. Mesmo os atos estatais que restringem direitos podem ser legítimos por ter como finalidade o interesse público de promover ou garantir um valor ou direito digno de tutela constitucional.

Diferentemente do Estado de Direito Liberal, em que a função do Estado e do próprio advogado público está marcada pelo abstencionismo e pela manutenção do status quo, no Estado de Direito de cunho Social o advogado público exerce um importante papel na formulação de políticas públicas legítimas, em que o interesse público deve estar conectado com a promoção de valores constitucionais. A própria tutela da dignidade da pessoa humana depende da 
atuação do Poder Público em assegurar um mínimo existencial, como condição para exercício de direitos pelo homem, pelo cidadão e pelo trabalhador.

Portanto, o papel primordial da Advocacia Pública é a defesa dos interesses do Estado, assim entendido o Estado de Direito Democrático e Social, cabendo ao advogado público zelar pela interpretação e aplicação do Direito que concretize o ideal de justiça, por meio do respeito aos princípios densificadores do Estado de Direito, da democracia e da socialidade, conferindo efetividade aos valores materiais constitucionais.

\section{CONCLUSÃo}

A Constituição Federal de 1988 resultou de uma intensa discussão política a respeito das diversas ideologias que permeavam a sociedade brasileira, recémsaída de um regime ditatorial de mais de 20 anos. O embate entre as antigas e as novas forças políticas e sociais conferiu um caráter pluralista à Constituição, moldando a maneira do Poder Público se relacionar com o indivíduo. Além de uma preocupação com a liberdade individual e com a instauração de uma ordem democrática, havia um forte anseio de que esse documento jurídico fosse um instrumento transformador da realidade social e de redução das desigualdades.

Esses valores foram encampados no sistema jurídico constitucional por meio de princípios, sendo certo que alguns, pela relevância que possuem, são denominados de princípios constitucionais estruturantes. Através deles, pode-se determinar a essência e a natureza da Constituição, direcionando a interpretação e a aplicação de todas as normas constitucionais.

Os princípios estruturantes da Constituição Brasileira são resultantes da sedimentação histórica do ideal do Estado de Direito, assim, seriam o princípio do Estado de Direito em sentido estrito, o princípio democrático e o princípio da socialidade. Embora a natureza social do Estado não esteja prevista no caput do artigo 1ํㅡㅇ o princípio da socialidade é indissociável do Estado Democrático de Direito.

O princípio democrático diz respeito a quem é o titular do poder estatal, ou seja, se refere à formação, à legitimação e ao controle dos órgãos que exercem o poder organizado do Estado. O Estado de Direito, por sua vez, constitui a maneira como deve proceder a atividade estatal, impondo limites e vinculando o Estado como forma de garantir a liberdade individual e social, notadamente através do reconhecimento de direitos fundamentais, da legalidade administrativa e da proteção jurídica por meio de Tribunais Judiciais independentes. Por outro lado, a previsão do Estado Social na Constituição estabelece um determinado fim ao Estado.

Dentre os objetivos comuns aos princípios constitucionais estruturantes estão a garantia e a promoção da dignidade da pessoa humana, núcleo duro essencial e inviolável dos direitos fundamentais. Estes impõem uma configuração ao poder 
de decisão do Estado legitimado democraticamente, no sentido de que não só direciona o exercício do poder político a uma ordem e lhe dá forma, como também o limita e o vincula em conteúdo e alcance.

Nesse ponto, o processo histórico de sedimentação da Advocacia Pública confunde-se com a própria evolução do Estado de Direito, desde a defesa dos interesses do monarca no Estado Patrimonial até a sua consolidação na Constituição Federal de 1988, como instituição essencial à justiça e garantia do Estado de Direito Democrático e Social.

A Advocacia Pública está consagrada no Título IV da atual Carta, que trata "Da Organização dos Poderes", no Capítulo IV, intitulado de "Funções Essenciais à Justiça". Percebe-se, assim, que a Advocacia Pública não constou do Capítulo II, que regulamenta o Poder Executivo, mas sim em Seção própria (Seção II) do Capítulo IV, como princípio garantia do Estado de Direito Democrático e Social, cuja competência está fixada na própria Constituição Federal.

Aos advogados públicos foram conferidas as tarefas de consultoria jurídica e assessoramento jurídico do Poder Executivo, bem como de representação judicial e extrajudicial do ente público. Embora a Constituição Federal não tenha consagrado a Advocacia Pública Municipal, por simetria, devem ser aplicados os preceitos constitucionais aplicáveis à Advocacia- Geral da União e às Procuradorias Estaduais e do Distrito Federal.

A autonomia técnica do advogado público é garantida pelo artigo $7^{\circ}$, inciso I e artigo 31, §1ํㅡㄹ da Lei 8.906/94. Como os advogados públicos exercem a atividade de advocacia, nos termos do artigo $3^{\mathrm{o}}$, $\S 1^{\mathrm{o}}$ da citada Lei, gozam das mesmas prerrogativas outorgadas aos advogados em geral, principalmente a independência e a liberdade no exercício de sua função (artigo $7^{\circ}$ e artigo 31, §1º). Aliás, não faria qualquer sentido atribuir à Advocacia Pública o controle interno da atividade administrativa, mas privar-lhe da independência e da liberdade necessárias ao desempenho de sua tarefa constitucional.

A atividade de consultoria jurídica tem como objetivo orientar os agentes públicos sobre a interpretação e aplicação do direito quanto aos fatos administrativos que se apresentem. Em um Estado de Direito Democrático e Social, a Advocacia Pública não deve meramente legitimar decisões administrativas determinadas pelos gestores da coisa pública. No plano processual deve resguardar a juridicidade do ato administrativo em face de pretensões individuais infundadas ou, inclusive, rever atuações judiciais para adequação ao interesse público de concretizar os princípios que consubstanciam o Estado de Direito Democrático e Social.

Portanto, o papel primordial da Advocacia Pública é a defesa dos interesses do Estado, assim entendido o Estado de Direito Democrático e Social, cabendo ao advogado público zelar pela interpretação e aplicação do Direito que concretize o ideal de justiça, por meio do respeito aos princípios densificadores do Estado de 
A ADVOCACIA PÚBLICA COMO INSTITUIÇÃO ESSENCIAL AO ESTADO DE DIREITO DEMOCRÁTICO E SOCIAL

Direito, da democracia e da socialidade, conferindo efetividade aos valores materiais constitucionais.

\section{REFERÊNCIAS}

ALEXY, Robert. Direitos Fundamentais, ponderação e racionalidade. In:

Constitucionalismo Discursivo. Tradução Luís Afonso Heck. 4. ed. Porto Alegre, 2015.

ANDRADE, José Carlos Vieira de. Os direitos fundamentais na Constituição Portuguesa de 1976. 5. ed. Coimbra: Ed. Almedina, 2012.

BANDEIRA DE MELLO, Celso Antônio. Curso de Direito Administrativo. São Paulo: Editora Malheiros, 27. ed., 2010.

BARROSO, Luís Roberto. A Constituição Brasileira de 1988: uma introdução. Tratado de Direito Constitucional. V.1. In: MARTINS, Ives Gandra da Silva; MENDES, Gilmar Ferreira; NASCIMENTO, Carlos Valter do (coords). 2. ed. São Paulo: Editora Saraiva, 2012.

BARROSO, Luís Roberto. Prefácio. In: SARMENTO, Daniel (Org.). Interesses Públicos versus interesses privados: desconstruindo a supremacia do interesse público. Rio de Janeiro: Editora Lumen Iuris, 2005.

BINENBOJM, Gustavo. Da supremacia do interesse público ao dever de proporcionar um novo paradigma para o direito administrativo. In: SARMENTO, Daniel (Org.). Interesses Públicos versus interesses privados: desconstruindo a supremacia do interesse público. Rio de Janeiro: Editora Lumen Iuris, 2005.

BONAVIDES, Paulo. Curso de Direito Constitucional. 26. ed. São Paulo: Editora Malheiros, 2011.

BONAVIDES, Paulo. Teoria Constitucional da Democracia Participativa: por um Direito Constitucional de luta e resistência, por uma nova hermenêutica, por uma repolitização da legitimidade. 3. ed. São Paulo: Editora Malheiros, 2003.

BÖCKENFÖRDE, Ernst Wolfgang. Estudios sobre el Estado de Derecho y la democracia. Madrid: Editorial Trotta, 2000. 
CANOTILHO, José Joaquim Gomes. Direito constitucional e teoria da constituição. 7. ed. Coimbra: Ed. Almedina, 2003.

COMELLA, Víctor F. Una defensa del modelo europeo de control de constitucionalidad. Madrid: Marcial Pon, 2011.

CUNHA JÚNIOR, Dirley da. Curso de Direito Constitucional. 9. ed. Salvador: Editora JusPodivm, 2015.

DI PIETRO, Maria Sylvia Zanella. Direito Administrativo. 19. ed. São Paulo: Editora Atlas, 2006.

DWORKIN, Ronald. Levando os Direitos a sério. Tradução de Nelson Boeira. São Paulo: Martins Fontes, São Paulo, 2011.

DWORKIN, Ronald. O Império do Direito. Tradução de Jefferson Luiz Camargo. São Paulo: Martins Fontes, São Paulo, 1999.

FILHO, Manoel Gonçalves Ferreira. Curso de Direito Constitucional. 40. ed. São

Paulo: Editora Saraiva, 2015.

HÄBERLE, Peter. Hermenêutica Constitucional. A sociedade aberta dos intérpretes da Constituição: contribuição para interpretação pluralista e "procedimental" da Constituição. Tradução de Gilmar Ferreira Mendes. Porto Alegre, 2002.

HABERMAS, Jürgen. Sobre o nexo interno entre o Estado de direito e a democracia. Teoria Política - Obras escolhidas. Tradução: Lumir Nahodil, v. IV. Lisboa: Edições. 2015.

JUSTEN FILHO, Marçal. Conceito de interesse público e a 'personalização' do direito administrativo. Revista Trimestral de Direito Público, n. 26, 1999.

MADEIRA, Danilo Cruz. O papel da Advocacia Pública no Estado Democrático de Direito. Revista Virtual da AGU. Ano 10, n. 107, dez.,2010.

MADUREIRA. Claudio. Advocacia Pública. Belo Horizonte: Editora Forum, ANAPE, 2015. 
A ADVOCACIA PÚBLICA COMO INSTITUIÇÃO ESSENCIAL AO ESTADO DE DIREITO DEMOCRÁTICO E SOCIAL

MAZZILLI, Hugo Nigro. A Defesa dos Interesses Difusos em Juízo: meio ambiente, consumidor, patrimônio cultural, patrimônio público e outros interesses. 19. ed. São Paulo: Editora Saraiva 2006.

MIRANDA, Jorge. Manual de Direito Constitucional - Tomo II. 6. ed. Coimbra: Coimbra Editora, 2007.

MIRANDA, Jorge. Os novos paradigmas do Estado Social. In: Conferência no XXXVII Congresso Nacional de Procuradores de Estado, proferida em Belo Horizonte. Disponível no seguinte endereço eletrônico: <http://www.icjp.pt/sites/ default/files/media/1116-2433.pdf>, em 28 de setembro de 2011.

MOREIRA NETO, Diogo de Figueiredo. A advocacia de Estado revisitada: essencialidade ao Estado Democrático de Direito. In: GUEDES, Jefferson Carús; SOUZA, Luciane Moessa (Coord.). Advocacia de Estado: questões institucionais para a construção de um Estado de Justiça. Belo Horizonte: Editora Fórum, 2009.

NOVAIS, Jorge Reis. Direitos como trunfos contra a maioria - sentido e alcance da vocação contramajoritária dos direitos fundamentais no Estado Democrático de Direito. In: Direitos Humanos e Democracia. Rio de Janeiro: Editora Forense, 2007.

NOVAIS, Jorge Reis. Direitos Fundamentais nas Relações entre Particulares: do dever de protecção à proibição do défice. Coimbra: Editora Almedina, 2018.

NOVAIS, Jorge Reis. Direitos fundamentais e justiça constitucional em Estado de Direito democrático. Coimbra: Coimbra Editora, 2012.

NOVAIS, Jorge Reis. Direitos sociais- Teoria Jurídica dos Direitos Sociais enquanto Direitos Fundamentais. Coimbra: Coimbra Editora, 2010.

NOVAIS, Jorge Reis. Os princípios Constitucionais Estruturantes da República Portuguesa. Coimbra: Coimbra Editora, 2004.

NOVAIS, Jorge Reis. Teoria das formas políticas e dos sistemas de governo. Lisboa: AAFDL, 2017. 
SARLET, Ingo W. A eficácia dos direitos fundamentais. 7. ed. Porto Alegre: Livraria, 2007.

SARMENTO, Daniel. Direitos Fundamentais e relações privadas. 2. ed. Rio de Janeiro, 2006.

SILVA, José Afonso da. Curso de Direito Constitucional Positivo. 15. ed. São Paulo: Editora Malheiros, 1998. 